\title{
Firewood and hearths: Middle Palaeolithic woody taxa distribution from El Salt, stratigraphic unit Xb (Eastern Iberia)
}

\author{
Paloma Vidal-Matutano \\ PREMEDOC Research Group, Universitat de València, Departament de Prehistòria i Arqueologia, Blasco Ibáñez 28, 46010 València
}

\section{A R T I C L E I N F O}

\section{Article history:}

Available online $\mathrm{xxx}$

\section{Keywords:}

El Salt

Middle Palaeolithic

Charcoal analysis

Spatial analysis

Palimpsests

Combustion

\begin{abstract}
A B S T R A C T
Spatial analyses of Palaeolithic sites typically defined by hearth-related assemblages have been mostly based on lithic and faunal remains. By using spatial analysis methods in conjunction with analytical units with higher temporal resolution than typical stratigraphic units, synchronic and diachronic relationships between artifacts deposited during successive occupation events have been elucidated. Spatial analyses applied to archaeobotanical remains are scarce, and when available, are typically focused on carpological remains (seeds and fruits). The lack of spatial indicators among anthracological remains hampers obtaining significant data linked to the relationships established between the combustion features and scattered charcoal fragments recovered from excavated occupation surfaces. To address this problem, the charcoal assemblage from El Salt Stratigraphic Unit (SU) Xb (Archaeosedimentary Facies Association 2 [AFA 2]) is analyzed using spatial analysis methods. Results suggest that the integration of anthracological remains into a palimpsest dissection analyses is vital to better understand the relationship between combustion structures and activity areas. These results highlight the utility of spatial and statistical methods as important tools for future anthracological analyses to provide meaningful information related to taxa distribution and the last firewood used in combustion structures.
\end{abstract}

(c) 2016 Elsevier Ltd and INQUA. All rights reserved.

\section{Introduction}

The study of settlement patterns provides important data for the understanding of Palaeolithic lifestyles and these patterns are a key element in the analysis of the organization of space. Hearthrelated accumulations are a common feature in Palaeolithic sites and their spatial characterization is therefore fundamental to recognizing cultural processes involved in the formation of archaeological sites (Vaquero and Pastó, 2001; Vaquero et al., 2004; Polo-Díaz et al., 2015). The study of Palaeolithic campsites, typically defined as hearth-related assemblages, has previously been understood using ethnographic analogy to provide insight for understanding past human behaviour considering that this spatial configuration has proven to be a common feature among current hunter-gatherer groups (Brooks and Yellen, 1987; Gamble, 1991). Ethnoarchaeological studies have defined hearthrelated assemblages by the existence of accumulations of remains around multiple hearths. These areas have been linked to the development of activities based on family units embedded in a

E-mail address: paloma.vidal@uv.es. social structure (Clarke, 1977; Yellen, 1977; Binford, 1981, 1982; Whitelaw, 1983). Around these activity areas, many important subsistence tasks occurred, including processing and food consumption, production and maintenance of stone or wooden tools, as well as socialization activities (conversation, sleeping areas, playing areas, etc).

Two types of remains are typically utilized by researchers using spatial analyses techniques, which have guided ethnographic interpretation of Palaeolithic life-ways: lithic objects and zooarchaeological remains. The incorporation of lithic and faunal refits is a key element for the identification of synchronic and diachronic relationships between artifacts deposited during the development of successive occupation events (Gabucio et al., 2014; Polo-Díaz et al., 2015; Modolo and Rosell, 2016). In the Iberian Peninsula, research on current Middle Palaeolithic sites have focused on the study of archaeostratigraphic units from a spatiotemporal perspective, identifying abundant lithic recycling processes such as at El Cañaveral (Ortiz and Baena, 2015) and spatial connections between lithic refits and combustions structures in Abric del Pastor (Machado et al., 2013) and El Salt (Machado et al., 2016). For instance, a comparative study of faunal refits between units Ja and $\mathrm{H}$ from Abric Romaní has identified unexpected 
differences in occupations of the rock shelter, thus allowing the determination of synchronous relationships between activity and non-activity areas. While refitted faunal remains from unit Ja were distributed throughout the surface, faunal refits from unit $\mathrm{H}$ were only clustered around activity areas. This has been interpreted by the authors as indicative of different strategies in the use of space, with small groups possibly occupying a reduced space in unit $\mathrm{H}$ and larger groups with greater space requirements represented by the distribution of artifacts in unit Ja (Rosell et al., 2012).

As has been widely noted, the comparison between archaeological and ethnographic hearth-related assemblages has inherent difficulties due to different temporal resolutions, which are strongly related to different sedimentological development (Bailey, 2007; Henry, 2012). Thus, while in ethnoarchaeological models the time-scale is based in occupation events - which can be observed and measured - in archaeological contexts, we have only events inferred by relationships between artifacts and features (Vaquero et al., 2001). The difficulty in translating ethnographic observations onto the archaeological record is compounded by considering all recovered remains as coeval. This can lead to an interpretation that the accumulation of remains within the same stratigraphic unit is the result of several contemporaneous family units inhabiting the site rather than being the product of successive occupation episodes. This is a result of interpreting human behaviour from coarse analytical units, typically stratigraphic levels. Notwithstanding, spatial approaches to settlement analysis highlighting the time-averaged nature of the formation of material assemblages are increasingly abundant. Three-dimensional plotting of faunal and lithics using GIS software has become an essential tool to isolate anthropogenic assemblages stratigraphically synchronic within a single archaeological deposit (Vaquero et al., 2004, 2001; Marín Arroyo, 2009; Rosell et al., 2012; Vallverdú et al., 2012, 2005, Bargalló et al., 2015; Geiling and Marín-Arroyo, 2015; Machado and Pérez, 2015; Martínez-Moreno et al., 2015; Machado et al., 2016; Modolo and Rosell, 2016).

Spatial analyses of archaeobotanical remains are variable depending on the discipline and noticeably less common than in faunal or lithic studies. This may be due either to a traditional emphasis on both faunal and lithic proxies maintained by researchers reconstructing Palaeolithic human behaviour (Weiss et al., 2008) or to a preservation bias; that is, the organic nature of archaeobotanical residues decrease markedly the chances of them being detected in the archaeological record. Generally, archaeobotanical remains affected by combustion processes or by conditions of extreme aridity or humidity have greater chances at preservation (Thiébault, 1984; Chabal, 1988). In addition, the recovery of archaeobotanical remains requires specific sampling strategies adapted to the characteristics of each site. These sampling strategies are not currently systematically practiced during the excavation of Palaeolithic sites. While generally uncommon (as noted above), existing intrasite spatial analyses of archaeobotanical remains have mainly been applied to carpological materials. For example, researchers have used spatial analyses techniques on carpological materials from the Upper Palaeolithic site of Ohalo II to produce density and frequency maps of the rich macrobotanical assemblage, thus identifying several plantfood preparation areas (Weiss et al., 2008; Snir et al., 2015) and contributing to the study of the use and the organization of space by Upper Palaeolithic hunter-gatherers.

Analyzing the spatial distribution of anthracological remains using GIS software is still very uncommon, although some

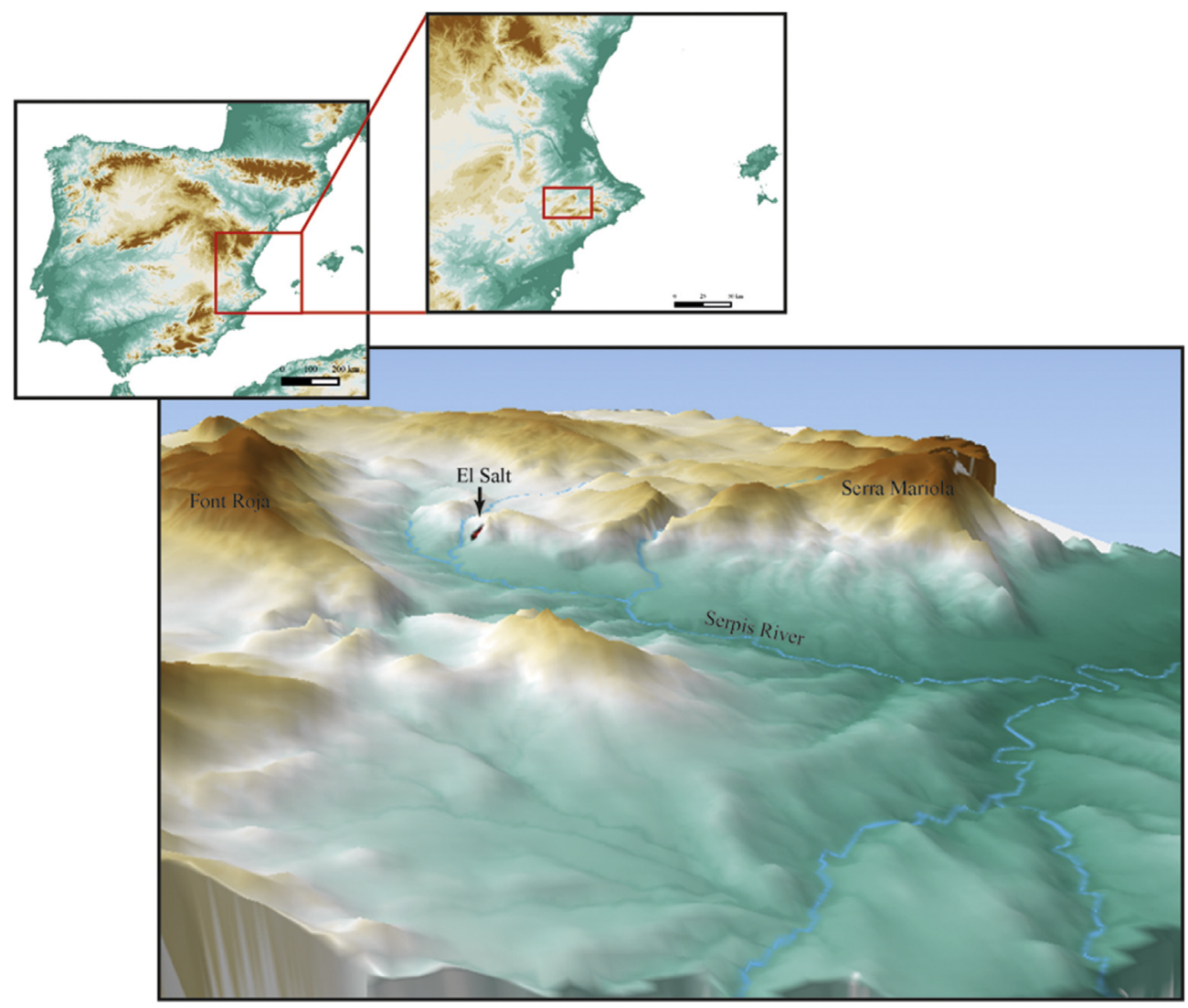

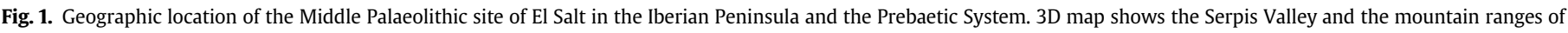
Font Roja and Mariola. 
pioneering works have highlighted the importance of studying the spatial distribution of scattered woody taxa along living surfaces (Heinz, 1990; Badal and Heinz, 1991). A charcoal spatial analysis by Thiébault (1995) from the site of Balme de Thuy is an important early work; however, the sampling method of hand-picking only larger fragments of charcoal lead to an overrepresentation of the most abundant taxa (Chabal, 1988; Badal and Heinz, 1991). More recently, the identification and analysis of more than 300 woodimprints at Abric Romaní resulted in an interpretation of differential use of space at the rock shelter. Two areas were defined: an outer area linked to the storing of firewood and an inner area closer to the combustion structures, with higher densities of charred wood related to combustion of firewood (Castro-Curel and Carbonell, 1995; Solé et al., 2013).

This research presents a spatial analysis of anthracological remains from the Middle Palaeolithic palimpsest deposit of El Salt. The goals with this study have been: 1 ) To provide evidence of the utility of existing analytical tools for the formulation of working hypotheses regarding the differential spatial distribution of anthracological remains, the clustering areas and the taxonomic dispersion; 2) To promote the inclusion of spatial analysis methods in anthracology in order to reach a more holistic understanding of the use and management of firewood, and finally, 3) To establish new procedures for the incorporation of the analysis of anthracological remains to better understand Palaeolithic deposits, which can lead to a more accurate characterization of human occupation dynamics.

\section{Material and methods}

\subsection{Site context and stratigraphic unit $\mathrm{Xb}$ excavation}

The site of El Salt is an open-air rock shelter located at $680 \mathrm{~m}$ a.s.l. in the mountainous region of Alicante, Eastern Iberia (Fig. 1). The Middle Palaeolithic sequence is represented by eight stratigraphic units (SU) (including SU XII to the middle of SU V) dating between $60.7 \pm 8.9$ and $45.2 \pm 3.4$ ka BP (Galván et al., 2014b). A Paleocene limestone wall $38 \mathrm{~m}$ in height formed at a thrust fault and covered with tufa and travertine gave refuge to the space occupied by humans at the bottom of the wall, which at times of maximum development covered almost the entire excavated surface. This deposit has been systematically excavated since 1986 with an integrated multidisciplinary approach based on obtaining higher temporal resolutions of analysis related to Neanderthal behaviour (Machado et al., 2011; Mallol et al., 2013a,b; Galván et al., 2014b; Garralda et al., 2014; Sistiaga et al., 2014, 2011; Machado and Pérez, 2015; Rodríguez-Cintas and Cabanes, 2015).

The context analyzed in this study belongs to the lower part of the SU X (Xb) dating to $52.3 \pm 4.6$ ka BP (Galván et al., 2014b). This unit is characterized by fine loose dark brown sand with a low sedimentation-rate, as estimated from sedimentary and chronological data (Mallol et al., 2013b; Galván et al., 2014a,b). The archaeo-sedimentary deposit included in this segment of the stratigraphic sequence represents a dense palimpsest of recurrent human occupations during which several activities were developed corresponding to the generic model of "hearth-related assemblages" (Vaquero and Pastó, 2001). Flat combustion features of various sizes (0.20-1 $\mathrm{m}$ diameter), principally located near the travertine wall described above, are associated with rich archaeological assemblages including faunal remains, lithic objects, limestone pebbles with use-wear and wood-charcoal fragments. At present, a total of 61 well-preserved simple combustion structures have been documented in SU X (Galván et al., 2014a,b). The microstratigraphy of some of these features is composed of a thick layer of white ash and a black layer of carbonized organic residue at the base of the feature formed by prior activities (Mallol et al., 2013b). However, in most cases the ashy layer is not wellpreserved.

A Harris matrix was utilized during the excavation of El Salt to accurately delimit and document single sedimentary facies and relevant interrelationships. All anthropogenic remains were recorded according to natural slope and microtopographical features while combustion features were excavated according to the available thin microstratigraphic layers: namely, the white ash layer and the black layer (Mallol et al., 2013b; Machado et al., 2016). Excavation of SU Xb has allowed the identification of an initial division of the palimpsest deposit into several fine-grained analytical units designated Archaeosedimentary Facies Associations (AFAs). These units correspond to the highest possible temporal resolution achievable within the context studied (Machado and Pérez, 2015; Machado et al., 2016). This research is focused on the anthracological remains recovered from the entire excavation surface of AFA $2\left(30 \mathrm{~m}^{2}\right)$, an archaeostratigraphic unit of $7 \mathrm{~cm}$ mean thickness defined using a geoarchaeological analysis of sedimentary facies, and a spatial analysis of lithics and faunal refits.

\subsection{Charcoal analysis}

During the 2013 and 2014 archaeological field seasons, systematic soil sampling of the entire excavated surface was conducted for water flotation, with the intention of separating macrobotanical remains from sediments. A small number of $\geq 2 \mathrm{~cm}$ charcoal fragments with a high degree of preservation ( $\mathrm{n}=7$ ) were hand-picked and recorded three-dimensionally (Fig. 2). Systematic sampling of wood-charcoal utilized various sieves with meshes of $1 \mathrm{~mm}$ for large residue and $0.2 \mathrm{~mm}$ for the flotation sample. Four combustion structures were identified in this archaeostratigraphic unit: $\mathrm{H} 44, \mathrm{H} 45, \mathrm{H} 53 \mathrm{~b}$ and H57. The smallest one was not available for sampling (H45), and two
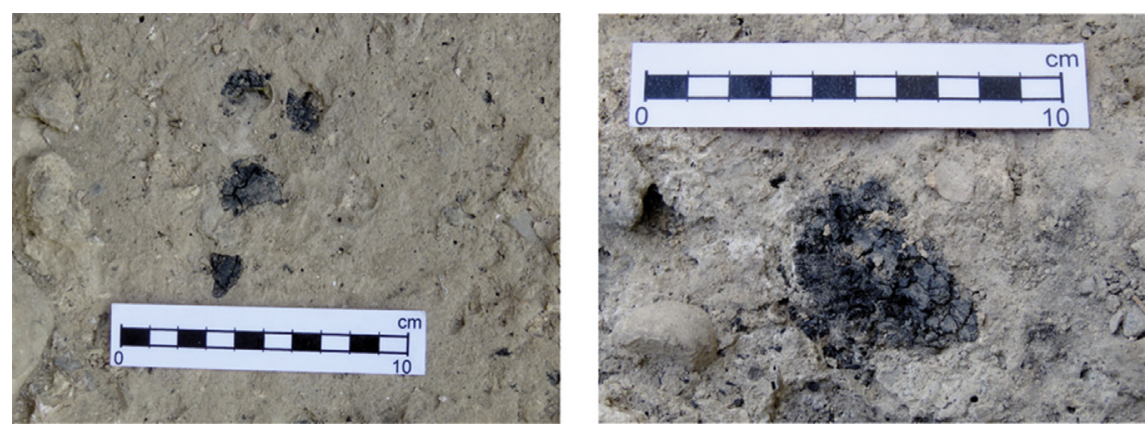

Fig. 2. Large wood charcoal fragments from the SU Xb surface. 
provided only sediment from the black layer (H44 and H53b). One yielded anthracological data from both the white and the black layer (H57). Each fragment of charcoal was manually fractured to provide transverse, tangential and radial sections for taxonomic identification using a Nikon Optiphot-100 brightfield/ darkfield incident light microscope with 50-500× magnification. Botanical identification was performed with specialized plant anatomy atlases (Jacquiot et al., 1973; Schweingruber, 1990) as well as the reference collection of modern charred woody taxa from the Laboratory of the Department of Prehistory and Archaeology, University of Valencia. Additionally, in order to study the fragmentation of charcoal each flotation sample was separated into four size-fractions with meshes ranging from $>4 \mathrm{~mm}, 2-4 \mathrm{~mm}, 1-2 \mathrm{~mm}$ and $<1 \mathrm{~mm}$.

\subsection{Spatial analysis of charcoal remains}

The spatial distribution of the anthracological record from El Salt AFA 2 was analyzed using GIS software (Quantum GIS v.2.10.1 "Pisa"). QGIS software allows for the integration and analysis of information associated with a specific geographic space as well as the establishment of relationships between different variables (Graser, 2013). The application of this program to charcoal fragments can generate density distributions of areas with the highest concentration of charcoal. These density maps are generated using statistical measures based on proximity calculations, including kernel estimation and the nearest neighbour algorithm. The results presented here were obtained using a radius of $25 \mathrm{~cm}$ as a measure of the standard deviation of distances between points. As the sediments from the excavated area were recovered in $50 \times 50 \mathrm{~cm}$ excavation units (sub squares), a random coordinate was assigned to each non-3D located wood charcoal fragment according to the unit designation. This method, as applied by previous researchers (e.g. Blasco et al., 2016), has allowed the production of horizontal spatial distribution maps to aid in the analysis of the spread of firewood remains within the rock shelter. Charcoal density has been calculated from the total of wood charcoal fragments per $50 \times 50 \mathrm{~cm}$ excavation units $\left(0.25 \mathrm{~m}^{2}\right)$. Additionally, the distribution of woody-taxa was completed using the QGIS "pie chart" tool.

\subsubsection{Statistical analysis of the spatial distribution}

Several statistical tools were applied to the charcoal analysis. First, K-means cluster analysis, a non-hierarchical method, was completed using R Statistical Package (Hartigan and Wong, 1979; R Core Team, 2013) to identify optimal wood-charcoal assemblages based on their relative spatial distribution, and to address possible correlations between the distribution of these clusters and the presence of combustion features presumed to be the nucleus of firewood dispersion. In order to obtain the optimum minimum number of clusters, the Elbow method was employed using a range of 2-15 clusters (Ketchen and Shook, 1996). Finally, distribution of charcoal was analyzed using spatial autocorrelation measures including the Nearest Neighbour Index (NNI). In order to characterize the degree of clustering and randomness of the distribution (Clark and Evans, 1955) NNI calculates the R statistic, a ratio of the observed average distance between nearest neighbours of a point distribution and the expected average distance between nearest neighbours, as determined by a comparative theoretical pattern. For each pattern, the shortest distance between all neighbours becomes the nearest distance, which is then averaged using all points. Hence, depending on the value of $\mathrm{R}$, different distribution trends can be identified, including: 1) Random distribution (Rvalue is close to 1 ); 2) Dispersed distribution ( $R$-value is close to 2 ) and 3) Clustered distribution (R-value is close to 0) (Wheatley and Gillings, 2002).

\section{Results and discussion}

\subsection{Palaeoecological inferences and firewood use among Neanderthal groups}

A total of 2.280 wood-charcoal fragments were identified from AFA 2. Most of the anthracological material was composed of scattered charcoal fragments recovered from the excavated surface $(\mathrm{n}=1595)$, while the concentrated assemblage (located within the combustion features) yielded a total of 685 wood-charcoal fragments. The scattered assemblage is characterized by the strong presence of Pinus nigra-sylvestris (Scots pine) followed by Acer sp. (maple) and with low values of other taxa such as Buxus sempervirens (bow), Fabaceae (the Legume Family), Juniperus sp. (junipers), Pistacia sp. (terebinth), Quercus (deciduous/evergreen oaks), Salix-Populus (willow/poplar) and Ulmaceae (Elm Family) (Table 1). The slight presence of ivy charcoal fragments (Hedera sp.) may be explained by incidental burning due to the ability of this plant to become entangled in other trees and shrubs in shady areas. From a palaeocological point of view, this vegetation record is indicative of a local landscape characterized by the prevalence of sub-humid supramediterranean conditions (MAT 8-13 ${ }^{\circ} \mathrm{C}$ and MAP $600-1000 \mathrm{~mm}$ ). These climatic values reflect a contrasting plant landscape as compared to that obtained from SU IV at Abric del Pastor, a MIS 4/5 Middle Palaeolithic site located approximately $4 \mathrm{~km}$ North from El Salt with dry and arid prevailing conditions (Vidal-Matutano et al., 2015).

Table 1

Anthracological data from the scattered charcoal assemblage of AFA 2.

\begin{tabular}{lll}
\hline Taxa & $\mathrm{n}$ & $\%$ \\
\hline Acer sp. & 110 & 6.90 \\
cf. Acer sp. & 2 & 0.13 \\
Angiosperms & 24 & 1.50 \\
Buxus sempervirens & 18 & 1.13 \\
cf. Buxus sempervirens & 2 & 0.13 \\
Conifers & 51 & 3.20 \\
Fabaceae & 7 & 0.44 \\
Hedera sp. & 5 & 0.31 \\
Juniperus sp. & 16 & 1.00 \\
Pinus nigra-sylvestris & 1315 & 82.45 \\
cf. Pinus nigra-sylvestris & 9 & 0.56 \\
Pistacia sp. & 1 & 0.06 \\
cf. Pistacia sp. & 1 & 0.06 \\
Quercus sp. & 24 & 1.50 \\
cf. Quercus sp. & 1 & 0.06 \\
Quercus deciduous & 1 & 0.06 \\
Quercus evergreen & 3 & 0.19 \\
Salix-Populus & 3 & 0.19 \\
cf. Salix-Populus & 1 & 0.06 \\
Ulmaceae & 1 & 0.06 \\
Total charcoal & $\mathbf{1 5 9 5}$ & $\mathbf{1 0 0}$ \\
Total taxa & $\mathbf{1 2}$ & \\
\hline
\end{tabular}

Limitations in genus or species identification in this analysis are due to the small size or poor preservation of some charcoal fragments identified during the botanical determination. In cases where specific species are not identifiable, such samples are identified at the level of genus or family (designated by $c f$.). Despite this difficulty, at least 11 plant taxa were identified, indicating a diverse botanical assemblage with multiple plant formations represented. Indeed, the strategic location of the rock shelter, surrounded by mountain ranges including Serra Mariola 
and the Font Roja, with an accessible plain close to the site (the Serpis Valley) generated a patchy landscape with varied wooded formations.

A total of six taxa were identified during analysis of the anthracological remains from combustion features at AFA 2 (Table 2). These taxa are also all represented within the scattered charcoal assemblage recovered from the excavating surface. As previously indicated, most of the sampled combustion structures yielded firewood remains from only the black layer; as the white layers were too poorly preserved to provide charcoal remains. This is common with samples from many Middle Palaeolithic combustion features, which typically exhibit post-depositional disturbances including human reworking, erosion and/or weathering (Albert et al., 2012; Aldeias et al., 2012; Goldberg et al., 2012). Hearth H57 is an exception to this expectation, with suitable anthracological samples recovered from both white ash and black layers. This hearth has provided a total of $253 \mathrm{cf}$. Acer sp. seed fragments contained in the white ash layer ( $G$. Pérez, personal communication). Further analysis of macrobotanical remains from combustion structure H57, in conjunction with other selected combustion features from El Salt, is currently being undertaken using a paleoeconomic approach with the intention of distinguishing possible firewood selection criteria related to hearth function (Vidal-Matutano and Théry-Parisot, 2016). this sense, NFT-3, a fire trampled on 21 consecutive days, provided significant information with the presence of calcitic ash into the black layer as reworked aggregates. Regarding faunal and lithic remains from black layers of El Salt any technological, quantitative or taxonomic difference has been observed compared to those from their adjacent and underlying sediment (Mallol et al., 2013b). Concerning anthracological data from this Middle Palaeolithic site, spatial analysis has strongly contributed to the observation of wood charcoal accumulations along the surface with higher density values located in some black layers (e. g. H44 or H57, compared to the adjacent squares). From a taxonomic point of view, two taxa (Pinus nigra-sylvestris and Acer sp.) are present at both microstratigraphic layers (ash/black layer) from the combustion features of AFA 2, while the other taxa (e. g. Quercus sp., Buxus sempervirens, Juniperus sp.) vary depending on each combustion structure, as it will be noticed. Although further micromorphological and anthracological data will be needed in order to explain the charcoal-rich nature from some of the black layers, three possible explanations for the anthracological formation processes of these layers could be suggested (Fig. 3): 1) The anthracological remains within the black layers could represent the charred residues of a precombustion occupation surface (Mallol et al., 2013b) (Fig. 3a); 2 ) The wood charcoal remains could correspond to successive firewood collection and burning events where the white layers

Table 2

Anthracological data from the combustion structures of AFA 2.

\begin{tabular}{|c|c|c|c|c|c|c|c|c|c|c|}
\hline \multirow{3}{*}{$\begin{array}{l}\text { Combustion structure } \\
\text { Layer } \\
\text { Tаха }\end{array}$} & \multirow{2}{*}{\multicolumn{2}{|c|}{$\frac{\mathrm{H} 44}{\text { Black layer }}$}} & \multirow{2}{*}{\multicolumn{2}{|c|}{$\frac{\mathrm{H} 53 \mathrm{~b}}{\text { Black layer }}$}} & \multirow{2}{*}{\multicolumn{2}{|c|}{$\frac{\text { H57 }}{\text { White layer }}$}} & \multirow{2}{*}{\multicolumn{2}{|c|}{$\frac{\mathrm{H} 57}{\text { Black layer }}$}} & \multirow{2}{*}{\multicolumn{2}{|c|}{ Total }} \\
\hline & & & & & & & & & & \\
\hline & $\mathrm{n}$ & $\%$ & $\mathrm{n}$ & $\%$ & $\mathrm{n}$ & $\%$ & $\mathrm{n}$ & $\%$ & $\mathrm{n}$ & $\%$ \\
\hline Acer sp. & 13 & 8.39 & 4 & 6.67 & 19 & 4.79 & 25 & 34.25 & 61 & 8.91 \\
\hline cf. Acer sp. & 1 & 0.65 & & & & & & & 1 & 0.15 \\
\hline Angiosperma & 5 & 3.23 & 1 & 1.67 & & & & & 6 & 0.88 \\
\hline Buxus sempervirens & 2 & 1.29 & & & 2 & 0.50 & 1 & 1.37 & 5 & 0.73 \\
\hline Coniferae & 5 & 3.23 & 7 & 11.67 & 8 & 5.56 & 2 & 2.74 & 22 & 3.21 \\
\hline Fabaceae & 1 & 0.65 & & & & & & & 1 & 0.15 \\
\hline Juniperus sp. & 1 & 0.65 & 4 & 6.67 & & & & & 5 & 0.73 \\
\hline Pinus nigra-sylvestris & 125 & 80.65 & 44 & 73.33 & 113 & 28.46 & 26 & 35.62 & 308 & 44.96 \\
\hline cf. Pinus nigra-sylvestris & 2 & 1.29 & & & & & 1 & 1.37 & 3 & 0.44 \\
\hline Quercus sp. & & & & & 2 & 0.50 & & & 2 & 0.29 \\
\hline cf. Acer sp. seeds & & & & & 253 & 63.73 & 18 & 24.66 & 271 & 39.56 \\
\hline Total remains & 155 & & 60 & & 397 & & 73 & & 685 & 100 \\
\hline Total taxa & 5 & & 3 & & 4 & & 3 & & 6 & \\
\hline
\end{tabular}

\subsubsection{Towards the characterization of the charcoal fragments from the black layers}

Excavation and identification of anthracological remains from black layers is important to correctly interpret the feature before attempting to deduce paleoeconomic dynamics as related to firewood use and management practices. Experimental and micromorphological data from El Salt has supplied significant data which allows for interpretation of black layers residues from combustion features likely to be representative of prior activities (Mallol et al., 2013b). Nevertheless, there is micromorphological evidence from archaeological and experimental combustion structures whose black layers include combustions remains and particles from the topsoil (Wattez, 1990). Micromorphological analyses from Palaeolithic sites such as Kebara or Abric Romaní have pointed out the presence of microcharcoal fragments associated to the black layers. In order to elucidate the nature of the archaeological combustion residues from El Salt, a series of experiments were carried out involving micromorphological, faunal and lithic analyses (Mallol et al., 2013b). In were either not preserved or scooped out before each new use (Fig. 3b); 3) They could be the result of a mixture of anthracological remains from previous combustion events along with some wood charcoal fragments which percolated down from the white ash layer of the new combustion feature (Fig. 3c).

\subsection{Firewood and spatial distribution: the anthracological contribution to the palimpsest dissection}

\subsubsection{Charcoal density by size fraction}

Density calculations using the total number of charcoal fragments recovered from AFA 2 are consistent with the results of preliminary lithic and faunal spatial analyses of materials recovered from archaeostratigraphic units from SU X. The greatest artifact density and majority of the combustion features have been recorded adjacent to the back wall of the site (Machado et al., 2011, 2016; Machado and Pérez, 2015). Consistent with these results, the highest density of charcoal fragments was also documented from the inner squares of the rock shelter, adjacent to the 
A
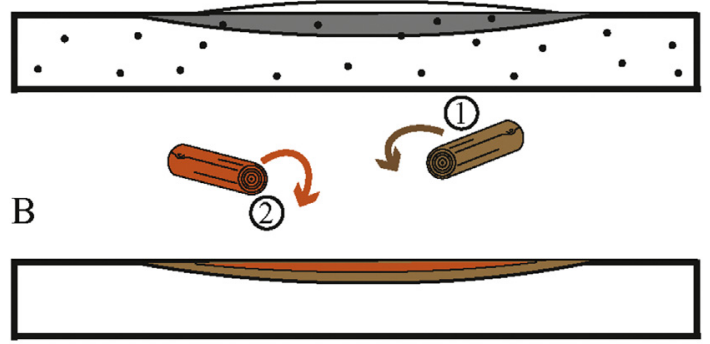

$\mathrm{C}$

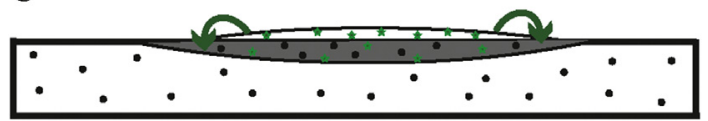

Fig. 3. Possible explanations for the anthracological formation processes of the black layers from El Salt.

location of the hearths (Fig. 4). Cluster analysis classified the charcoal distribution into four groups: Group 1, composed of materials recovered adjacent to the travertine wall and includes firewood remains from the squares close to combustion structures H44, H45 and H57; Group 2 is comprised of H53b and nearby charcoal accumulations. Groups 3 and 4 are located in the outer area of the rock shelter and exhibit a significant lower density of charcoal. The NNI index value $(R=0.65)$ indicates a pattern of random distribution of these remains.

Density analyses by charcoal size fraction yielded interesting results, indicating the differential spatial distribution of firewood remains. The larger wood charcoal fragments (size fraction $>4 \mathrm{~mm}$ and $2-4 \mathrm{~mm}$ ) tended to be located in discrete areas as compared to the combustion features, reflecting a greater presence of this size fraction in the outer squares of the rock shelter (Fig. 5). In comparison, smaller fragments $(1-2 \mathrm{~mm}$ and $<1 \mathrm{~mm}$ ) were located closer to the fireplaces creating charcoal clusters around and within the combustion structures (Fig. 6). The cluster analysis organized the charcoal remains into similar groups for the two intermediate size fractions ( $2-4 \mathrm{~mm}$ y $1-2 \mathrm{~mm}$ ), which account for the majority of the total charcoal samples recovered from AFA 2. This cluster

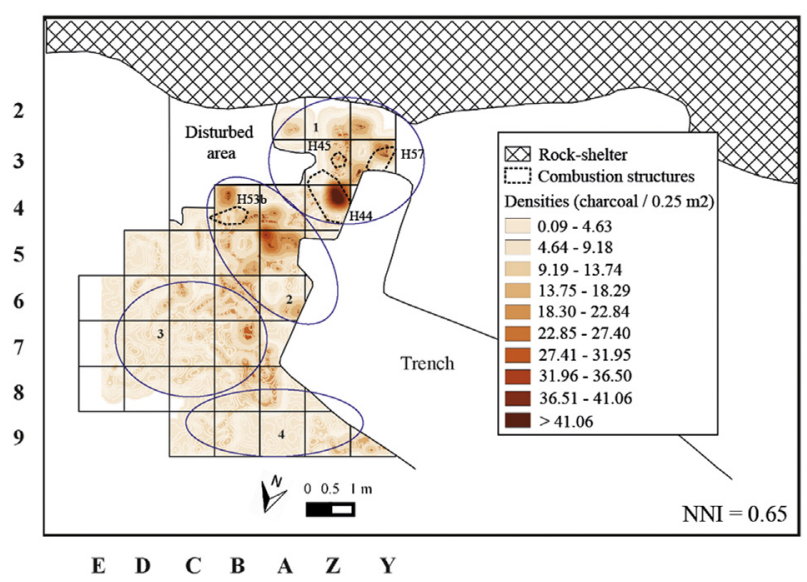

Fig. 4. Density map of the wood charcoal fragments recovered in AFA 2. Cluster analysis results are represented with blue circles. (For interpretation of the references to colour in this figure legend, the reader is referred to the web version of this article.)

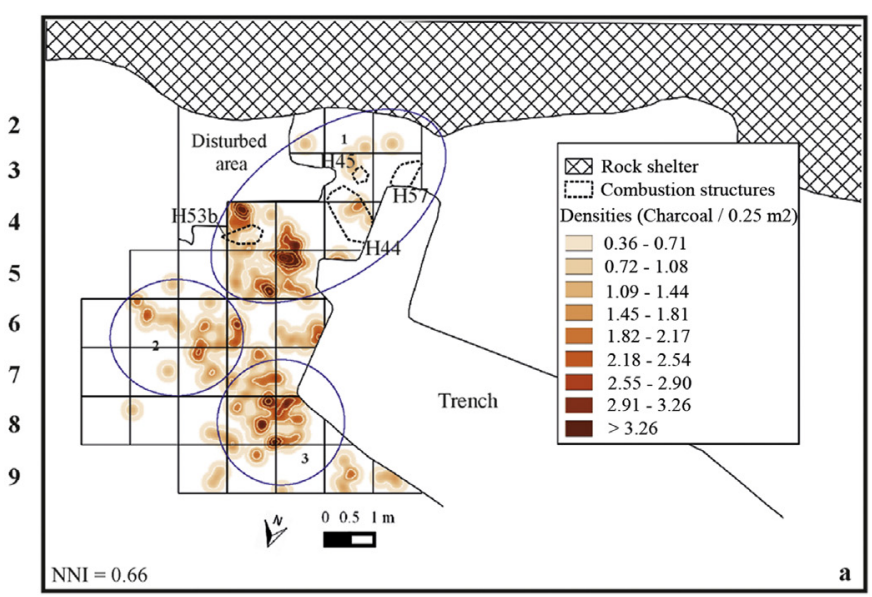

$$
\begin{array}{lllllll}
\text { E } & \mathbf{D} & \mathbf{C} & \mathbf{B} & \mathbf{A} & \mathrm{Z} & \mathbf{Y}
\end{array}
$$

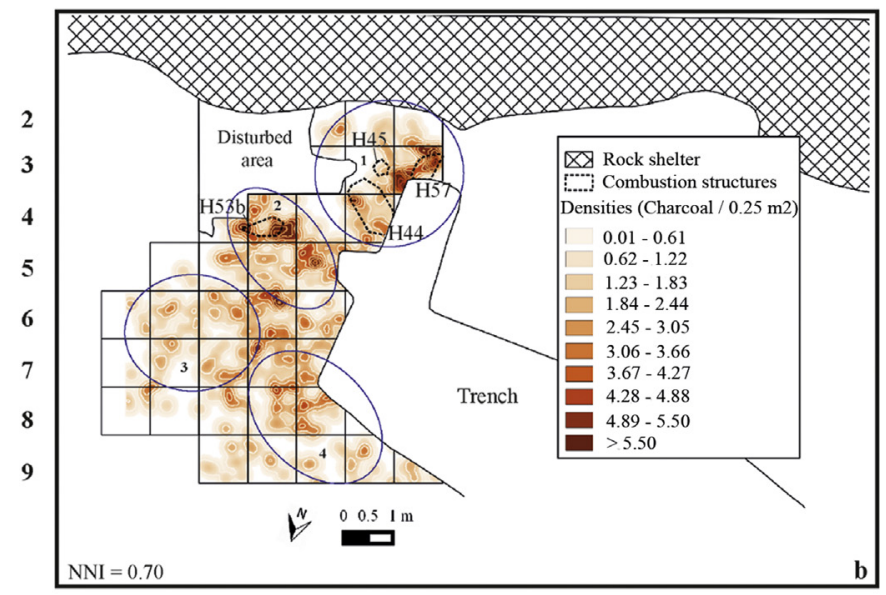

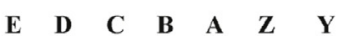

Fig. 5. Spatial distribution of charcoal remains by size fraction: $>4 \mathrm{~mm}$ (a) and 2-4 $\mathrm{mm}$ (b). Cluster analysis results are represented with blue circles. (For interpretation of the references to colour in this figure legend, the reader is referred to the web version of this article.)

classification is similar to the K-means cluster results from the total charcoal density from AFA 2. Thus, these size groups are important in weighting the general distribution pattern of the charcoal assemblage. Further indications of the distribution of charcoal fragments by size fraction come from the location of the smallest fragments $(<1 \mathrm{~mm})$. The distribution of this material is the opposite of the larger fragments, as they are mainly concentrated within the inner area around the combustion features. The cluster analysis of the smallest fragments indicates a division of the inner area into two areas: one zone is spatially related to hearth $\mathrm{H} 57$; the second area is distributed around hearths H53b and H44. NNI values (see Figs. 5 and 6) indicate a random distribution of all size fractions.

The differential spatial distribution of charcoal fragments as related to the size fraction has been observed in other archaeostratigraphic units from SU X of El Salt (Vidal-Matutano, 2016). However, additional data is required to better interpret the significance of this spatial distribution. An explanation for the highpreservation of large fragments of charcoal outside the area adjacent to the combustion features is required. The results of the spatial analysis presented here generally fit Binford's observations of the Nunamiut sites (Binford, 1982, 1978), where a model of cultural formation processes linked to hearth-related assemblages was established with a differentiation of activity areas. While small bones and lithic objects characterized a "drop 


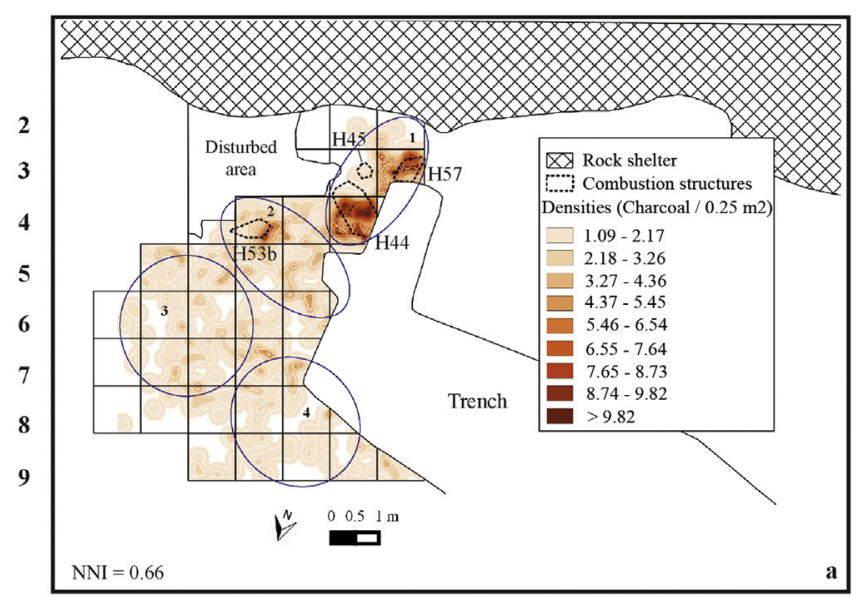

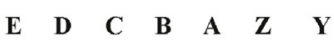

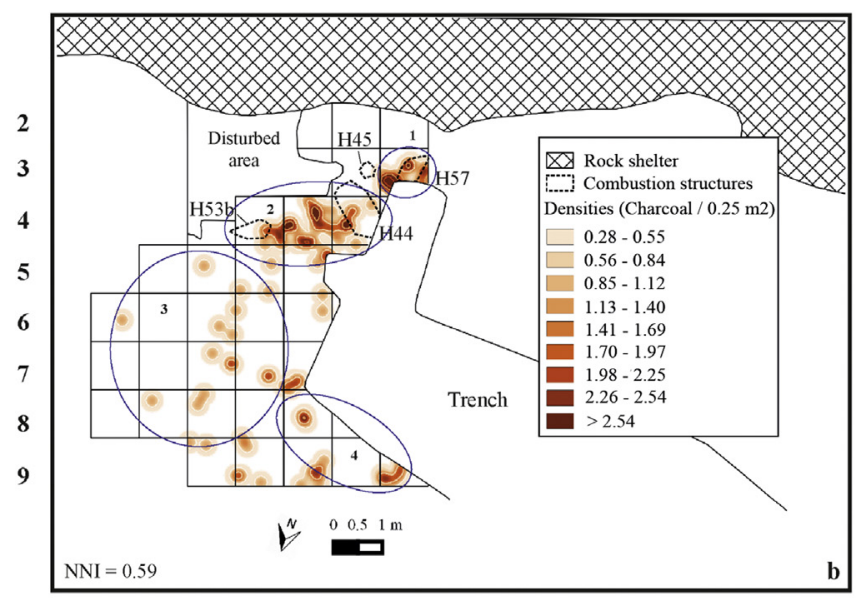

$\begin{array}{lllllll}\text { E } & \mathbf{D} & \mathbf{C} & \mathbf{B} & \mathbf{A} & \mathbf{Z} & \mathbf{Y}\end{array}$

Fig. 6. Spatial distribution of charcoal remains by size fraction: 1-2 $\mathrm{mm}$ (a) and $<1 \mathrm{~mm}$ (b). Cluster analysis results are represented with blue circles. (For interpretation of the references to colour in this figure legend, the reader is referred to the web version of this article.)

zone" as the result of in situ working activities, a "toss zone" included larger items intentionally swept to more distant areas away from activity areas. While this model fits the distribution seen at El Salt, another possibility is that the concentration of the smallest wood charcoal fragments in and around the hearth area could be due to charcoal fragmentation derived from fire processes. Further micromorphological data and spatial distribution analyses focussing on wood charcoal fragments are needed to test the anthropogenic impact of the area surroundings the combustion features.

\subsubsection{The distribution of individual taxa}

This research presents a spatial distribution analysis of woody taxa used by Neanderthal groups during several occupations to estimate the distribution and concentration of individual woodytaxa and charcoal fragments. With this aim, density maps were derived using two frequently identified woody-taxa in the anthracological record of AFA 2, Pinus nigra-sylvestris and Acer sp. (Fig. 7), as well as from two infrequent identified woody-taxa, including Quercus sp. and Buxus sempervirens (Fig. 8). The most salient characteristic observable when examining the taxa distribution maps is that the location of the four taxa is not random. Different taxa are distributed in different areas. Plant distributions

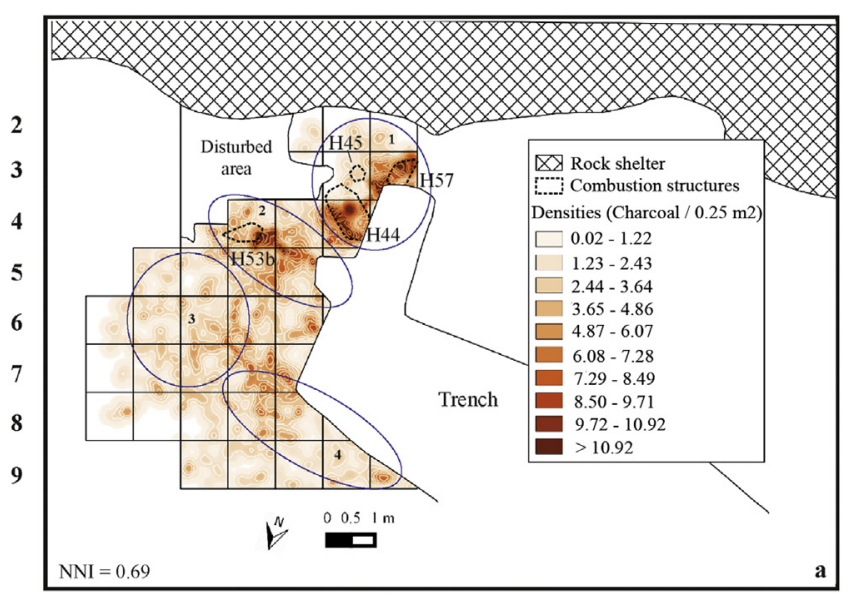

$\begin{array}{llllllll}\text { E } & \mathbf{D} & \mathbf{C} & \mathbf{B} & \mathbf{A} & \mathbf{Z} & \mathbf{Y}\end{array}$

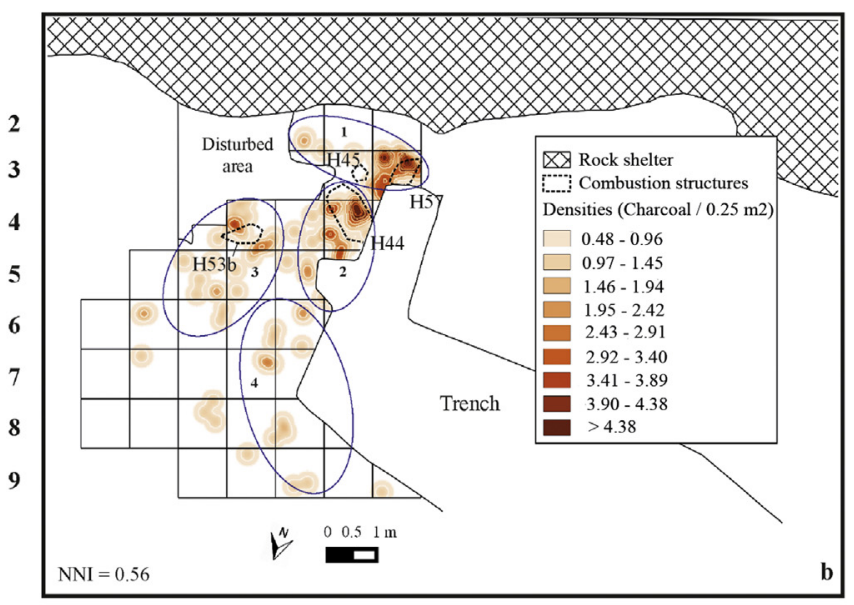

$\begin{array}{llllllll}\text { E } & \mathbf{D} & \mathbf{C} & \mathbf{B} & \mathbf{A} & \mathbf{Z} & \mathbf{Y}\end{array}$

Fig. 7. Spatial distribution of charcoal remains by taxa: Pinus nigra-sylvestris (a) and Acer sp. (b). Cluster analysis results are represented with blue circles. (For interpretation of the references to colour in this figure legend, the reader is referred to the web version of this article.)

are correlated with several taxa that cluster around specific combustion features. This last observation is connected to the frequency of taxa, because the most frequent species are usually the most prevalent on occupation surfaces, while the least frequent taxa are spatially discrete, and may reflect unusual consumption patterns.

Although the $\mathrm{K}-$ means analysis provided the same number of clusters for the four considered taxa, it is clear that they do not establish the same spatial relationships with the combustion features. Pinus nigra-sylvestris (Fig. 7a) is distributed throughout almost the entire excavated surface and is the most abundant taxa identified in the assemblage (comprising more than $80 \%$ of the total). In fact, this species is present in all sub-squares of the grid, although it's more common in the inner area adjacent to the hearths. The spatial distribution pattern of Pinus nigra-sylvestris is very similar to that of the intermediate size fractions in general, reflecting the predominance of this taxon in the total density of the archaeostratigraphic unit assemblage. On the other hand, Acer sp. is strongly concentrated in squares $\mathrm{Y} 3-\mathrm{Z} 4$, located around hearths H57 and H44 (Fig. 7b). Charcoal fragments from Acer sp. clusters into four groups. The first three groups demonstrate a spatial autocorrelation with combustion structures H57, H45, H44 and $\mathrm{H} 53 \mathrm{~b}$, while the fourth group aggregates the scattered fragments from the outer squares. 


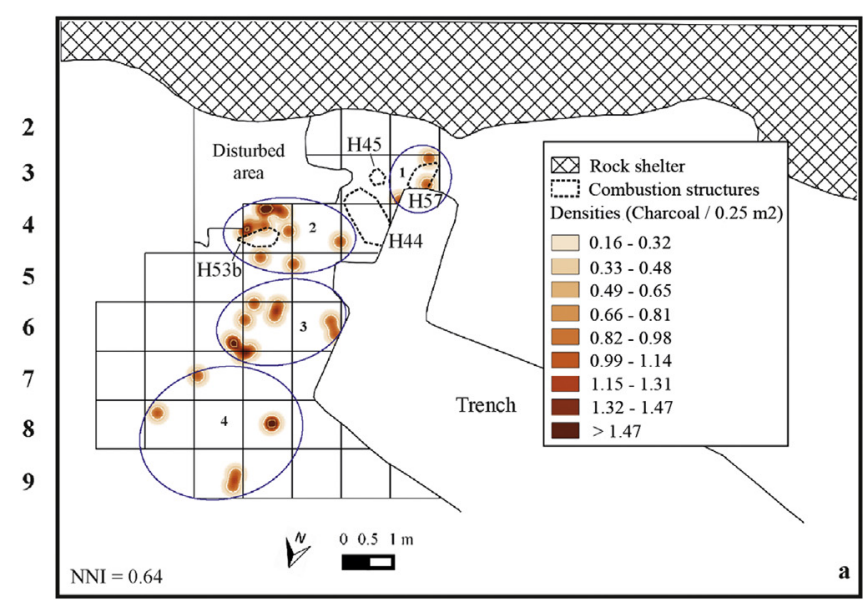

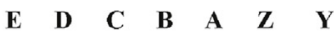

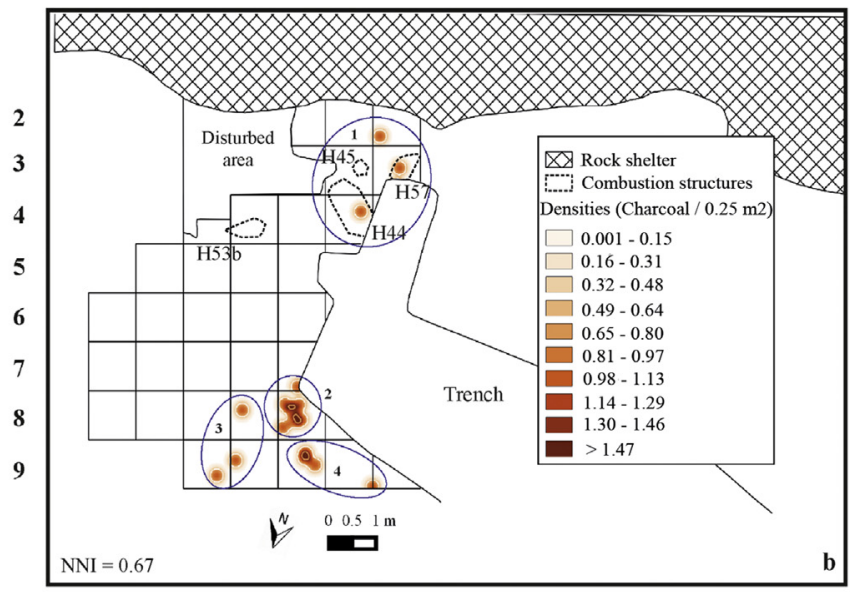

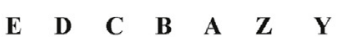

Fig. 8. Spatial distribution of charcoal remains by taxa: Quercus sp. (a) and Buxus sempervirens (b). Cluster analysis results are represented with blue circles. (For interpretation of the references to colour in this figure legend, the reader is referred to the web version of this article.)
The least commonly recovered taxa have proven to be the most suitable in demonstrating the contribution of a spatial analysis of anthracological remains to understanding the palimpsest nature of the archaeological deposits at El Salt. The Quercus sp. remains were distributed over four distinct groups; two of the groups are located in the outer area, and two are located in the inner area (Fig. 8a). The second group is particularly interesting as it represents an accumulation of oak fragments around hearth H53b. Only the black layer of this combustion structure could be sampled and any Quercus sp. charcoal fragment was identified. According to this, we could interpret this charcoal accumulation around this hearth as probable residues from the firewood used during the combustion event. This interpretation is supported by evidence from the charcoal analysis of H57, where Quercus sp. wood fragments were identified both in the white ash layer and within the adjacent subsquares.

Buxus sempervirens firewood remains were also divided into four spatially discrete clusters (Fig. 8b). Groups 2-4 are located in the outer squares and directly related to any combustion feature. However, disturbance caused by a trench from excavations conducted in 1960 prevents obtaining data that would further elucidate any associations between these charcoal fragments and possible nearby combustion features. However, Buxus sempervirens charcoal fragments included in the first group are useful in a detailed time-scale analysis. Some fragments are present in the ash layer of hearth H57 (likely the last firewood burned), whereas other fragments were contained within the black layer of hearth H44. Hence, we posit two plausible explanations for the presence of boxwood within the black layer of hearth H44. The boxwood may have been used as firewood in hearth $\mathrm{H} 44$, with the percolation of some fragments from the ash layer to the black layer (Fig. 9a); or, combustion structure H44 may have been lighted later than H57 on a surface containing the scattered firewood remains from previous combustion events (Fig. 9b). These two scenarios are not mutually exclusive, and possibly both situations played an important role in the anthracological formation processes from combustion feature contexts at El Salt.

Finally, as has been previously noted in the discussion of total charcoal density and size fraction analyses, NNI values for the individual taxa dispersions reflect a random spatial distribution. The statistical significance of these values may be related to the sampling method used in the recovery of charcoal fragments.

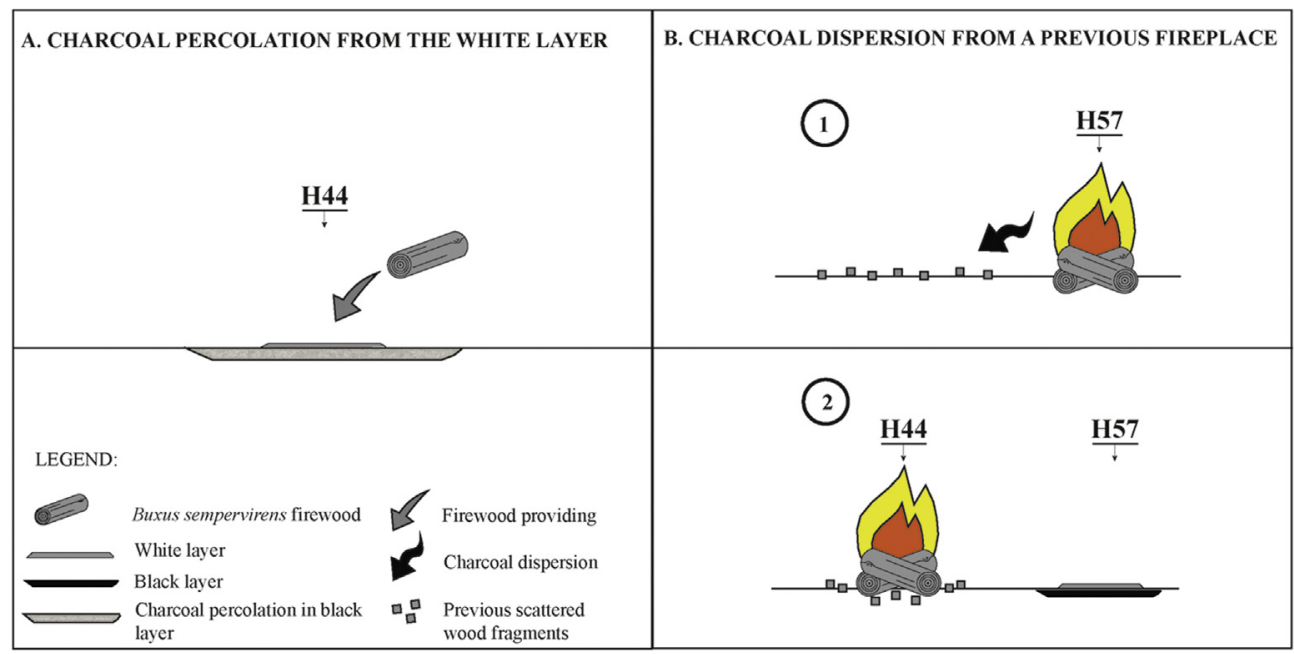

Fig. 9. Explanatory hypotheses for the formation of combustion features H44 and H57 black layers. 
Ongoing research indicates the potential for fictitious clustering patterns when sampling strategies such as hand-sorting are used and compared to systematic wet sieving or flotation methods (Vidal-Matutano, 2016). Unless a taxon is highly clustered in a particular area, the results from the flotation method will likely provide random NNI values, as flotation provides information regarding the total taxon spread over the excavated surface.

\subsubsection{Taxa dispersion: which firewood for which combustion} feature?

Because the entire excavated surface was sampled and analysed using the same methodology, the distribution pattern of firewood remains does not appear to reflect sampling biases; rather, the distribution pattern likely represents the use and management of firewood by Neanderthal groups throughout the occupation events. Thus, the woody plant assemblage from AFA 2 provides a representative picture of some of the activities linked to combustion of firewood. The taxa whose distributions are discrete (Quercus sp. and Buxus sempervirens) are concentrated within two groups of combustion features: hearth H53b (Quercus sp.) and hearths H44, H45 and H57 (Buxus sempervirens) (Fig. 10). Although anthracological data utilized here cannot provide insight into the temporal relationship between individual combustion events, the infrequent taxa have proven able to define specific spatial areas related to these events. For example, square Y3 demonstrates a copious carpological record constituting an archaeobotanical unit as close as possible to "ethnographic time", as the seeds and charcoal fragments from the ash layer contributes to our understanding about the last firewood used as well as the pyrotechnological activities performed (Vidal-Matutano and Théry-Parisot, 2016).

\section{Conclusions}

The research presented here contributes to the understanding of the woody taxa distribution within a Middle Palaeolithic hunter-gatherer campsite. Although the isolation of archaeological contexts representing "ethnographic time" remains a difficult obstacle for Palaeolithic archaeologists to overcome, defining

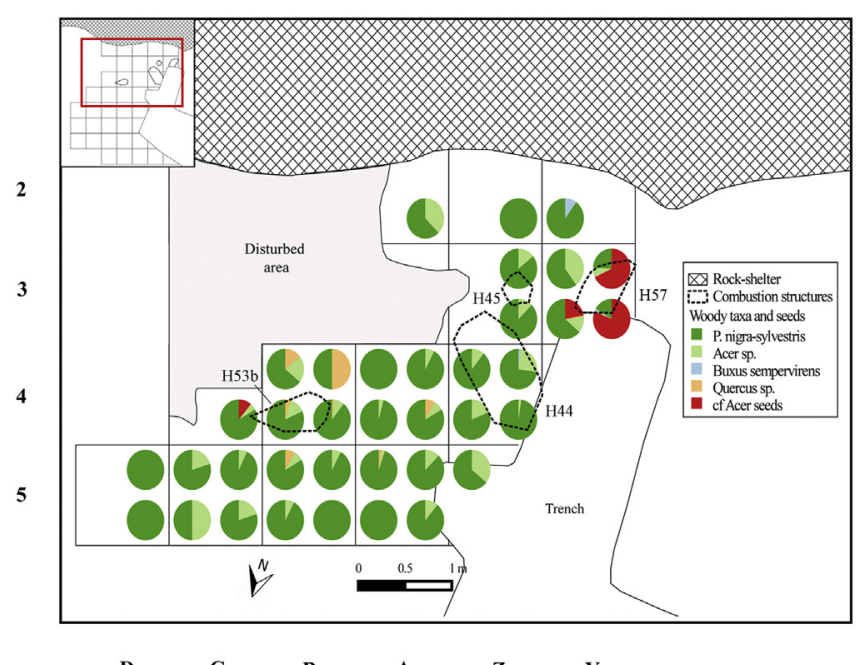

Fig. 10. Spatial distribution of the frequent and infrequent taxa considered in this work around the combustion structures area. Note the discrete distribution of Quercus sp. in squares B4-B5 and the concentration of carpological remains within the white layer of H57. high-resolution analytical units within palimpsest deposits such as those present at El Salt allow researchers to obtain a finegrained time-scale with much smaller temporal resolution than the stratigraphic unit, which may incorporate multiple distinct occupations with potentially different settlement and subsistence strategies (Vaquero and Pastó, 2001; Vallverdú et al., 2005; Aldeias et al., 2012; Rosell et al., 2012; Gabucio et al., 2014; Bargalló et al., 2015; Machado and Pérez, 2015; MartínezMoreno et al., 2015; Polo-Díaz et al., 2015; Modolo and Rosell, 2016). Although these analytical units may reflect "micro-palimpsests" still resulting from several occupation episodes, they can contribute to a more accurate temporal framework suitable for the recognition of firewood spatial patterns. Charcoal analyses from Palaeolithic sites must take into account the palimpsest-like nature of most of these sites in order to provide significant implications for understanding firewood use and management by human hunter-gatherer groups. The spatial analysis methodology presented in this research is a promising tool that should be further utilized and refined in future anthracological analyses to visualize charcoal density and taxa distribution throughout an excavated surface, and can be used to provide further insight into the nature of the last firewood used in combustion features, especially when the ashy layer is not preserved and charcoal accumulations can be identified in the surroundings of the combustion structures. In these cases, such as the Quercus wood fragments around hearth $\mathrm{H} 53 \mathrm{~b}$, spatial analysis can provide interesting data about the nature of scattered anthracological assemblages close to combustion features. Specifically, identification of rarely occurring taxa is key to understanding the nature of the palimpsest deposit, coupled with a sampling strategy that accounts for the microstratigraphy of Paleolithic combustion features (including black and white layers). Hearths H57 and H44 provide an ideal example of the complicated task of defining the nature of the charcoal remains from black layers, as the identified fragments may represent either fuel residues percolated from white ash layers or the results of prior activities not associated with a following combustion event. Further research utilizing a taphonomic and palaeoeconomic approach to charcoal analysis may provide information regarding the spatial association between firewood remains from white ash/black layers and the scattered occupation surface assemblages. Finally, results from ongoing micromorphological, lithics and faunal analyses from the archaeostratigraphic units of SU X excavated at El Salt can supplement this analysis by providing a more holistic understanding of the use of space by Neanderthal groups and the activities that occurred during successive human occupations.

\section{Acknowledgements}

This work was carried out as a component of a Ph.D Dissertation at the Department of Prehistory and Archaeology (University of Valencia, Spain) with the financial support of a VALi+d pre-doctoral grant (ACIF/2013/260). Archaeological and anthracological research at El Salt was funded under the Spanish Government project " $\mathrm{La}$ desaparición de los grupos neandertales en la region central del Mediterráneo Ibérico. Una propuesta metodológica de aproximación al proceso histórico y al marco paleoambiental" (HAR2012-32703, MICINN-FEDER), and Direcció General de Cultura (Conselleria d'Educació, Cultura i Esports, Generalitat Valenciana). I would like to express my gratitude to the El Salt team members for their help with field sampling tasks. I also thank Carolina Mallol, who provided comments on the spatial distribution of the charcoal fragments by size fraction and Cristo Hernández, Bertila Galván, Salvador Pardo and the anonymous reviewers who helped to improve the earlier versions of this paper. Special thanks to Justin $P$. 
Rego for helping with the English corrections of the manuscript. Finally, I would like to thank the 6th International Anthracology Meeting organizers for inviting me to participate in this special volume.

\section{References}

Albert, R.M., Berna, F., Goldberg, P., 2012. Insights on Neanderthal fire use at Kebara Cave (Israel) through high resolution study of prehistoric combustion features: evidence from phytoliths and thin sections. Quaternary International 247, 278-293.

Aldeias, V., Goldberg, P., Sandgathe, D., Berna, F., Dibble, H.L., McPherron, S.P., Turq, A., Rezek, Z., 2012. Evidence for Neandertal use of fire at Roc de Marsal (France). Journal of Archaeological Science 39, 2414-2423.

Badal, E., Heinz, C., 1991. Méthodes utilisées en Anthracologie pour l'étude de sites préhistoriques. BAR International Series 573, 17-47.

Bailey, G., 2007. Time perspectives, palimpsests and the archaeology of time. Journal of Anthropological Archaeology 26, 198-223.

Bargalló, A., Gabucio, M.J., Rivals, F., 2015. Puzzling out a palimpsest: testing an interdisciplinary study in level $\mathrm{O}$ of Abric Romaní. Quaternary International. http://dx.doi.org/10.1016/j.quaint.2015.09.066.

Binford, L.R., 1982. The archaeology of place. Journal of Anthropological Archaeology $1,5-31$.

Binford, L.R., 1981. Behavioral archaeology and the "Pompeii premise". Journal of Anthropological Research 37 (3), 195-208.

Binford, L.R., 1978. Nunamiut Ethnoarchaeology. Academic Press, New York.

Blasco, R., Rosell, J., Sañudo, P., Gopher, A., Barkai, R., 2016. What happens around a fire: faunal processing sequences and spatial distribution at Qesem Cave (300 ka), Israel. Quaternary International 398, 190-209.

Brooks, A.S., Yellen, J.E., 1987. The preservation of activity areas in the archaeological record: ethnoarchaeological and archaeological work in northwest Ngamiland, Botswana. In: Kent, S. (Ed.), Method and Theory for Activity Area Research: an Ethnoarchaeological Approach. Columbia University Press, pp. 63-106.

Castro-Curel, Z., Carbonell, E., 1995. Wood pseudomorphs from level I at Abric Romaní, Barcelona, Spain. Journal of Field Archaeology 22, 376-384.

Chabal, L., 1988. Pourquoi et comment prélever les charbons de bois pour la période antique: les méthodes utilisées sur le site de Lattes (Hérault). Lattara 1, $187-222$.

Clark, P.J., Evans, F.C., 1955. On some aspects of spatial pattern in biological populations. Science 121, 397-398.

Clarke, D.L., 1977. Spatial Archaeology. Academic Press, New York.

Gabucio, M.J., Cáceres, I., Rosell, J., Saladié, P., Vallverdú, J., 2014. From small bone fragments to Neanderthal activity areas: the case of level $\mathrm{O}$ of the Abric Romaní (Capellades, Barcelona, Spain). Quaternary International 330, 36-51.

Galván, B., Hernández, C.M., Mallol, C., Machado, J., Sistiaga, A., Molina, F.J., Pérez, L.J., Afonso, R., Garralda, M.D., Mercier, N., Morales, J.V., Sanchis, A., Tarriño, A., Gómez, J.A., Rodríguez, Á., Abreu, I., Vidal, P., 2014a. El Salt. The last Neanderthals of the Alicante mountains (Alcoi, Spain). In: Sala, R. (Ed.), Pleistocene and Holocene Hunter-Gatherers in Iberia and the Gibraltar Strait: the Current Archaeological Record. University of Burgos and Atapuerca Foundation, Burgos, pp. 380-388.

Galván, B., Hernández, C.M., Mallol, C., Mercier, N., Sistiaga, A., Soler, V., 2014b. New evidence of early Neanderthal disappearance in the Iberian Peninsula. Journal of human evolution $75,16-27$.

Gamble, C., 1991. An introduction to the living spaces of mobile peoples. In: Gamble, C. (Ed.), Ethnoarchaeological Approaches to Mobile Campsites: HunterGatherer and Pastoralist Case Studies. International Monographs in Prehistory, pp. $1-24$.

Garralda, M.D., Galván, B., Hernández, C.M., Mallol, C., Gómez, J.A., Maureille, B., 2014. Neanderthals from El Salt (Alcoy, Spain) in the context of the latest middle Palaeolithic populations from the southeast of the Iberian Peninsula. Journal of Human Evolution 75, 1-15.

Geiling, J.M., Marín-Arroyo, A.B., 2015. Spatial distribution analysis of the lower Magdalenian human burial in El Mirón Cave (Cantabria, Spain). Journal of Archaeological Science 60, 47-56.

Goldberg, P., Dibble, H., Berna, F., Sandgathe, D., McPherron, S.J., Turq, A., 2012. New evidence on Neandertal use of fire: examples from Roc de Marsal and Pech de l'Azé IV. Quaternary International 247, 325-340.

Graser, A., 2013. Learning QGIS 2.0. Packt Publishing Ltd, Birmingham.

Hartigan, J.A., Wong, M.A., 1979. Algorithm AS 136: a k-means clustering algorithm. Journal of the Royal Statistical Society. Series C (Applied Statistics) 28, $100-108$

Heinz, C., 1990. Méthodologie et paléoécologie du gisement préhistorique de l'Abeurador (Hérault) au passage mésolithique/néolithique, d'aprés l'analyse des charbons de bois: premiers résultats. Pact 22 (4), 219-229.

Henry, D., 2012. The palimpsest problem, hearth pattern analysis, and Middle Paleolithic site structure. Quaternary International 247, 246-266.

Jacquiot, C., Trenard, Y., Dirol, D., 1973. Atlas d'anatomie des bois des angiosperms (Essences feuillues). Paris.

Ketchen, D.J., Shook, C.L., 1996. The application of cluster analysis in strategic management research: an analysis and critique. Strategic Management Journal 17, 441-458.
Machado, J., Hernández, C.M., Galván, B., 2011. Contribución teórico-metodológica al análisis histórico de palimpsestos arqueológicos a partir de la producción ítica. Un ejemplo de aplicación para el Paleolítico medio en el yacimiento de El Salt (Alcoy, Alicante). Recerques del Museu d'Alcoi 20, 33-46.

Machado, J., Hernández, C.M., Mallol, C., Galván, B., 2013. Lithic production, site formation and Middle Palaeolithic palimpsest analysis: in search of human occupation episodes at Abric del Pastor Stratigraphic Unit IV (Alicante, Spain). Journal of Archaeological Science 40, 2254-2273.

Machado, J., Molina, F.J., Hernández, C.M., Tarriño, A., Galván, B., 2016. Using lithic assemblage formation to approach middle Palaeolithic settlement dynamics: El Salt stratigraphic Unit X (Alicante, Spain). Archaeological and Anthropological Sciences. http://dx.doi.org/10.1007/s12520-016-0318-z.

Machado, J., Pérez, L., 2015. Temporal frameworks to approach human behaviour concealed in Middle Palaeolithic palimpsests: a high-resolution example from El Salt Stratigraphic Unit X (Alicante, Spain). Quaternary International. http:// dx.doi.org/10.1016/j.quaint.2015.11.050.

Mallol, C., Hernández, C.M., Cabanes, D., Machado, J., Sistiaga, A., Pérez, L., Galván, B., 2013a. Human actions performed on simple combustion structures: an experimental approach to the study of Middle Palaeolithic fire. Quaternary International 315, 3-15.

Mallol, C., Hernández, C.M., Cabanes, D., Sistiaga, A., Machado, J., Rodríguez, Á. Pérez, L., Galván, B., 2013b. The black layer of Middle Palaeolithic combustion structures. Interpretation and archaeostratigraphic implications. Journal of Archaeological Science 40, 2515-2537.

Marín Arroyo, A.B., 2009. Assessing what lies beneath the spatial distribution of a zooarchaeological record: the use of GIS and spatial correlations at El Mirón Cave (Spain). Archaeometry 51, 506-524.

Martínez-Moreno, J., Torcal, R.M., Sunyer, M.R., Benito-Calvo, A., 2015. From site formation processes to human behaviour: towards a constructive approach to depict palimpsests in Roca dels Bous. Quaternary International. http:// dx.doi.org/10.1016/j.quaint.2015.09.038.

Modolo, M., Rosell, J., 2016. Reconstructing occupational models: bone refits in level I of Abric Romaní. Quaternary International. http://dx.doi.org/10.1016 j.quaint.2015.12.098.

Ortiz, I., Baena, J., 2015. Experiments around the fire. Discovering human and natural processes in Middle Paleolithic hearths. Anthropologie 53, 501-518.

Polo-Díaz, A., Benito-Calvo, A., Martínez-Moreno, J., Mora, R., 2015. Formation processes and stratigraphic integrity of the Middle-to-Upper Palaeolithic sequence at Cova Gran de Santa Linya (Southeastern Prepyrenees of Lleida, Iberian Peninsula). Quaternary International. http://dx.doi.org/10.1016 j.quaint.2015.10.113.

R Core Team, 2013. A Language and Environment for Statistical Computing. R Foundation for Statistical Computing, Viena.

Rodríguez-Cintas, Á., Cabanes, D., 2015. Phytolith and FTIR studies applied to combustion structures: the case of the middle Paleolithic site of El Salt (Alcoy, Alicante). Quaternary International. http://dx.doi.org/10.1016/ j.quaint.2015.09.043.

Rosell, J., Blasco, R., Fernández-Laso, M.C., Vaquero, M., Carbonell, E., 2012. Connecting areas: faunal refits as a diagnostic element to identify synchronicity in the Abric Romaní archaeological assemblages. Quaternary International 252 $56-67$.

Schweingruber, F.H., 1990. Anatomy of European Woods. Bern y Stuttgart, Haupt.

Sistiaga, A., Mallol, C., Galván, B., Summons, R.E., 2014. The Neanderthal meal: a new perspective using faecal biomarkers. PLoS ONE 9 (6), e101045.

Sistiaga, A., March, R.J., Hernández, C.M., Galván, B., 2011. Aproximación desde la química orgánica al estudio de los hogares del yacimiento del Paleolítico medio de El Salt (Alicante, España). Recerques del Museu d'Alcoi 20, 47-70.

Snir, A., Nadel, D., Weiss, E., 2015. Plant-food preparation on two consecutive floors at Upper Paleolithic Ohalo II, Israel. Journal of Archaeological Science $53,61-71$.

Solé, A., Allué, E., Carbonell, E., 2013. Hearth-related wood remains from Abric Romani layer M (Capellades, Spain). Journal of Anthropological Research 4 535-559.

Thiébault, S., 1995. Functioning of hearths and ancient vegetation at the Balme de Thuy (Haute-Savoie, France). The charcoal contribution. Quaternaria Nova 5, 129-170.

Thiébault, S., 1984. Les apports de l'anthracologie à l'archéobotanique. Nouvelles de l'Archéologie. Supplément à MSH Informations Paris 18, 33-37.

Vallverdú, J., Allué, E., Bischoff, J. Cáceres, I., Carbonell, E., Cebrià, A., GarcíaAntón, D., Huguet, R., Ibáñez, N., Martínez, K., 2005. Short human occupations in the middle Palaeolithic level I of the Abric Romaní rock-shelter (Capellades, Barcelona, Spain). Journal of Human Evolution 48, 157-174.

Vallverdú, J., Alonso, S., Bargalló, A., Bartrolí, R., Campeny, G., Carrancho, Á Expósito, I., Fontanals, M., Gabucio, J., Gómez, B., 2012. Combustion structures of archaeological level $\mathrm{O}$ and Mousterian activity areas with use of fire at the Abric Romaní rockshelter (NE Iberian Peninsula). Quaternary International 247, $313-324$.

Vaquero, M., Chacón, G., Fernández, C., Martínez, K., Rando, J.M., 2001. Intrasite spatial patterning and transport in the Abric Romaní middle Paleolithic site (Capellades, Barcelona, Spain). In: Conard, N.J. (Ed.), Settlement Dynamics of the Middle Paleolithic and Middle Stone Age, vol. 1. Tübingen Publications in Prehistory, pp. 573-595.

Vaquero, M., Pastó, I., 2001. The definition of spatial units in Middle Palaeolithic sites: the hearth-related assemblages. Journal of Archaeological Science 28 $1209-1220$. 
Vaquero, M., Rando, J., Chacón, G., 2004. Neanderthal spatial behaviour and social structure: hearth-related assemblages from the Abric Romaní Middle Palaeolithic site. In: Conard, N.J. (Ed.), Settlement Dynamics of the Middle Paleolithic and Middle Stone Age 2, pp. 367-392.

Vidal-Matutano, P., 2016. Around the Fire: Landscape, Climate and Firewood Management in Hunter-gatherer Groups during the Middle Palaeolithic (Alicante, Spain) (Unpublished Doctoral dissertation). Universitat de València.

Vidal-Matutano, P., Hernández, C.M., Galván, B., Mallol, C., 2015. Neanderthal firewood management: evidence from Stratigraphic Unit IV of Abric del Pastor (Eastern Iberia). Quaternary Science Reviews 111, 81-93.

Vidal-Matutano, P., Théry-Parisot, I., 2016. The earliest evidence of a smoking hearth? A Palaeoeconomical Approach from El Salt (Eastern Iberia). In: Proceedings of the 6th Annual ESHE Meeting, Madrid (Spain).
Wattez, J., 1990. Dynamique de Formation des Structures de Combustion de la Fin du Paléolithique au Néolithique Moyen. Approche Méthodologique et Implications Culturelles (Unpublished Doctoral dissertation). Université de Paris I.

Weiss, E., Kislev, M.E., Simchoni, O., Nadel, D., Tschauner, H., 2008. Plant-food preparation area on an Upper Paleolithic brush hut floor at Ohalo II, Israel. Journal of Archaeological Science 35, 2400-2414.

Wheatley, D., Gillings, M., 2002. Spatial Technology and Archaeology: the Archaeological Applications of GIS. Taylor and Francis, London and New York.

Whitelaw, T., 1983. People and space in hunter-gatherer camps: a generalizing approach in ethnoarchaeology. Archaeological Review from Cambridge 2, 48-66.

Yellen, J.E., 1977. Archaeological Approaches to the Present: Models for Reconstructing the Past. Academic Press, New York. 